\title{
Ağrı Destinasyonunun Alternatif Turizm Potansiyeline İlişkin Yerel Paydaşların Bakış Açısı
}

\author{
Hasan Önal ŞEYHANLIOĞLU ${ }^{1}$ ve Said KINGIR ${ }^{2}$
}

$\ddot{\mathrm{Oz}}$

Alternatif arayış çerçevesinde kitle turizminden kaçış, bireyleri alternatif turizm türlerine yöneltirken, destinasyonların kalkınması ve tanınması adına da önem kazanmıştır. Böylelikle bölgeye gelen turistlerin bıraktığı döviz ulusal bazda bölgeler arası ekonomik farkı da minimize edecektir. Araştırmanın amac1, alternatif turizm konusunda Ağrı destinasyonunda yaşayan yerel paydaşların görüşleri ve destinasyonun turizm potansiyelinin incelenmesi olup, nitel bir araştırma olarak tasarlanmıştır. Araştırma verileri A ğrı destinasyonunda bulunan bazı yerel yönetim temsilcileri, sivil toplum kuruluşları, yerel halk, kamu çalışanları, serbest meslek erbapları ve bazı özel sektör işletmelerinden (girişimcilerden) yarı-yapılandırılmış görüşme formu yardımıyla elde edilmiştir. Çalışma Ağrı destinasyonunun ekonomi, alt yapı, girişimcilik düzeyi, sosyal yaşam, turizm işletmeleri, yöresel el sanatları, tanıtım-pazarlama bakımından incelemeyi esas almıştır. Araştırma bulgularına göre özellikle; tanıtımın, imaj çalışmalarının, kaliteli turizm işletmelerinin, ulaşılabilirliğin, medya kullanımının, etkinliklerin ve çekiciliklerin arttırılması konularına önem verilmesi ele alınmıştır. Elde edilen bulgular ışığında yerel paydaşlara ve araştırmacılara bazı öneriler geliştirilmeye çalışılmıştır.Etkinlikler anlamında gelen turistin fazla vakit geçirmesi için çeşitli etkinlikler yapılmalıdır.Tanıtım ve pazarlama çalışmaları arttırılmalıdır. Sosyal medya etkin kullanılmalı ve Ağrı destinasyonu tamamen her özelliği ile tanıtilmalidır.

Anabtar Kelimeler: Alternatif Turizm, Yerel Paydaşlar, Tanıtım, Ağrı İli

\section{Local Stakeholders’ Perspective on Alternative Tourism Potential of Ağrn Destination}

\begin{abstract}
Escape from mass tourism within the framework of alternative search has gained importance in the name of development and recognition of destinations while directing individuals to alternative types of Tourism. In this way, the foreign exchange left by tourists coming to the region will minimize the economic difference between regions on a national basis. The aim of the research is to examine the views of local stakeholders living in Ağr1 destination on alternative tourism and the tourism potential of the destination and is designed as a qualitative research. Research data was obtained using a semi-structured interview form from some local government representatives, nongovernmental organizations, local residents, public employees, self-employed professionals and some private sector businesses (entrepreneurs). The study focused on the economy, infrastructure, level of entrepreneurship, social life, tourism enterprises, local crafts, promotion and marketing of the Ararat destination. According to the research findings, in particular; emphasis has been placed on promotion, Image studies, quality tourism enterprises, accessibility, media use, events and attractiveness. In light of the findings, some recommendations have been developed to local stakeholders and researchers. Activities should be done in order for the tourist to spend more time in the sense of activities. Promotion and marketing efforts should be increased. Social media should be used effectively and the pain destination should be fully promoted with every feature.
\end{abstract}

Key Words: Alternative Tourism, Local Stakeholders, Publicity, Ağr1 Province

Atıf İçin / Please Cite As:

Şeyhanlıŏlu, H. Ö. ve Kıngır, S. (2021). Ağrı destinasyonunun alternatif turizm potansiyeline ilişkin yerel paydaşların bakış açısı. Manas Sosyal Araștırmalar Dergisi, 10(1), 619-634.

Geliş Tarihi / Received Date: 23.10.2020

Kabul Tarihi / Accepted Date: 02.12.2020

\footnotetext{
${ }_{1}$ Öğr. Gör. - Ağr1 İbrahim Çeçen Üniversitesi Doğubayazıt Ahmed-i Hani Meslek Yüksekokulu, hseyhanlioglu@agri.edu.tr

(iD ORCID: 0000-0002- 9056-5237

2 Prof. Dr. - Sakarya Uygulamalı Bilimler Üniversitesi Turizm Fakültesi, saidkingir@sakarya.edu.tr

(iD ORCID: 0000-0002-5459-3484
} 


\section{Giriş}

Kitle turizminden kaçış olarak görülen alternatif turizm günümüzde ön plana çıkmıştır. Bu ön plana çıkışın en büyük sebeplerinden biri de şüphesiz ki; 2020 yılını etkisi altına alan Covid-19 salgınıdır. Korona virüsün bulaşmasının en büyük sebebi temastır. Çünkü virüs temas sonucu yaygınlığını arttırıyor. Bu yaşanan gelişmeler turizm sektörünü de etkilemektedir. Bireyler kitlenin olduğu yerlerden kaçarak daha sakin ve temasın az olduğu tatilleri tercih etmektedirler. Turistik ürün artık daha kişiselleştirilmiş biçimde sunulmaktadır (Gössling, Scott ve Hall, 2020, s. 2; Arıca, 2019). Böylece turistler artık alternatif turizm ürünlerine ve destinasyonlarına yönelmişlerdir.

Alternatif turizm, ulusal bazda değerlendirildiğinde yerel paydaşlara, ülke ekonomisine ve ödemeler dengesine katkı sunmaktadır. Bir ilde sanayi çok iyi olabilir lakin girişimciler daha ucuz üretim noktasını bulduğunda o ildeki fabrikalarla çalışmak istemeyebilirler. Lakin turizm süreklilik arz eden ve sürdürülebilir turizm kapsamında politikalarla daima devam edecek bir işleyiştir. Çünkü turizm planlamasını daha doğru planlandığında turist sayısı artar ve gelir sağlar. Doğru alternatif turizm planlaması hem göçü engeller hem de bireylerin tüm yıl boyunca istihdam edilmesini sağlar. Bilhassa küçük Anadolu şehirleri için alternatif turizm önem taşımaktadır.

Ağnı destinasyonu birçok turistik ürünü ile büyük bir alternatif turizm madenidir. Çünkü bakıldığında kültür turizmi, sağlık ve termal turizm, inanç turizmi, kış turizmi, mağara turizmi, kuş ve endemik bitki gözlemciliği gibi birçok alternatif turizm çeşitlerinin çoğunu içinde barındırmaktadır. Bu yönüyle Türkiye turizmi açısından önemli bir destinasyondur. Yerel paydaşların tesisleşme, turist çekme, gelen turisti en az bir gece konaklamasını sağlama gibi konulara önem vermeleri gerekmektedir.

Araştırma kapsamında Ağrı ilinde yaşayan yerel paydaşların alternatif turizm bağlamındaki görüşlerine yer verilmiştir. Ağrı ilini yakından tanıyan gerçekten konu hakkında fikir sahibi olan bireyler ön planda değerlendirilmiştir. Çalışmanın amacı Ağrı destinasyonunun turizm potansiyelini ve yerel paydaşların alternatif turizme bakış açısını ortaya koymaktadır.

\section{Literatür İncelemesi}

\section{Alternatif Turizm ve Paydaşlar Teorisi}

Alternatif turizm, klasik olan kitle turizminin olumsuz etkilerini azaltmak amacıyla oluşturulmuş, yeni turistik ürünlerin bir araya gelmesiyle oluşan bir turizm anlayışıdır (Hacioğlu ve Avcıkurt, 2008, s. 9; Ulusan ve Batman, 2010; Zengin, Koç ve Ulama, 2019; Isaac ve Eid, 2019). Başka bir diğer tanıma göre alternatif turizm, etkinliklerin belirli bir çerçeve ile sınırlandırılmasından ve bu sinırlandırmanın yol açtı̆̆ problemlerden arınarak özel ilgi alanlarına yöneltme çabaları olarak tanımlanabilir (Çelik, 2018, s. 194; Kuq ve Hasanaj, 2020). Daha detaylı olarak bakıldığında: çeşitli turizm aktiviteleri sayesinde turistlerin vakit geçirmesini sağlayan, turizmi mevsimsellikten kurtaran yerel paydaşları bir arada tutan turizm anlayışıdır.

Günümüzde bilhassa COVID-19 salginından sonra değeri artan alternatif turizm niteliksel olarak kitle turizmi ile kıyaslandığında birçok avantajı bulunmaktadır (Samarathunga ve Gamage, 2020, s. 2). Son zamanlarda bireyler daha çok sosyal mesafe kurallarına uymak ve salgına yakalanmamak için kitle turizmini daha az tercih etmektedirler. Alternatif turizmi kitle turizminden ayıran özellikler aşağıda verilmiştir (Baytok, Pelit ve Soybalı, 2017, s. 6; Kozak ve Bahçe, 2012; Wearing ve Neil, 2009, s. 5):

- Daha mikro ölçektedir.

- Yerel halkı öncelikli temel alır.

- Doğal, kültürel ve tarihi kaynakları önemseyen ve taşıma kapasitesini dikkate alan bir gelişim gösterir.

- Gelişim sürecinde tüm sosyal paydaşların katılımını öngörür.

- Alternatif turizm ürünleri sürdürülebilir turizm felsefesini temel alarak, hem yerel halkın hem de tüketicinin yaşam kalitesini arttıracak nitelikte olmalıdır.

- Alternatif turizmde sosyal, fiziksel kapasite ve ekonomik rasyonellik arasindaki uyum önemlidir.

- Yerel halk ile turistler arasındaki pozitif iletişimi öngören, doğal, sosyal ve toplumsal değerler ile tutarlı çevre bilincini ön planda sergiler.

- Kitlesel hareketler, kalabalık gruplar yerine küçük gruplar ve/veya bireysel turizm faaliyetlerini ön planda tutar. 
Alternatif turizm türleri kapsamına bakılacak olursa, Üçüncü yaş turizmi, Gençlik turizmi, Kırsal turizm, Eko-turizm, Yayla turizmi, Botanik turizmi, Kültür turizmi, İnanç turizmi, Kongre turizmi, Sağllk turizmi, Mağara turizmi, Kış turizmi, Av turizmi, Yat turizmi, Golf turizmi, Gastronomi turizmi, Kamp ve Karavan turizmi başlıcalarıdır (Hacığlu ve Avcıkurt, 2008; Düşmezkalender ve Metin, 2019; Arslan, 2019; Jovicic, 2016; Nunkoo ve Gürsoy, 2017; Prince ve Ioannides, 2017).

Paydaşlar teorisi, bir bölgede, yörede turizm kolu için yer alan kesimleri ifade eder. Bunların içinde kamu kurumları, turizm işletmeleri, yerel halk, sivil toplum kuruluşları, turistler ifade edilebilir. Bu teoriye göre tüm paydaşlar neredeyse her yaptıkları faaliyetleri ve aldığı kararlarda doğrudan veya dolaylı olarak ilişki içerisinde olduğu tüm hedef gruplarını dikkate alması gerektiğini öngörür (Yıldırım, 2020, s. 440; Chan, Nozu ve Cheung, 2020, s. 1866; Amerta, 2017, s. 21; Baytok vd., 2017, s. 6). Bilhassaişleyişin akış1 turizm işletmeleri adına önemlidir. Çünkü müşterilere karşı olumsuz bir imajı olan işletmenin ayakta kalması zordur. $\mathrm{Bu}$ nedenle, sosyal sorumluluk projeleri, kampanyalar ve yardımlar gibi adımlar diğer paydaşların düşüncesini olumlu olarak etkilemektedir.

Bölge için işletmenin tutundurma çabaları yanında yerel halkın bakış açısı da önemlidir. Çünkü destinasyonu ziyaret eden turist internet sitelerinde yapılan yorumlara ve geldiğinde yerel halkla iletişime geçmektedir. Turistlerin yerel halkın önerdiği işletmeler çerçevesinde bilgiler toplayıp tercihler yapmaktadırlar (Wong, Lai ve Tao, 2020). Turizm paydaşlar teorisi elemanları Şekil 1'de yer almaktadır.

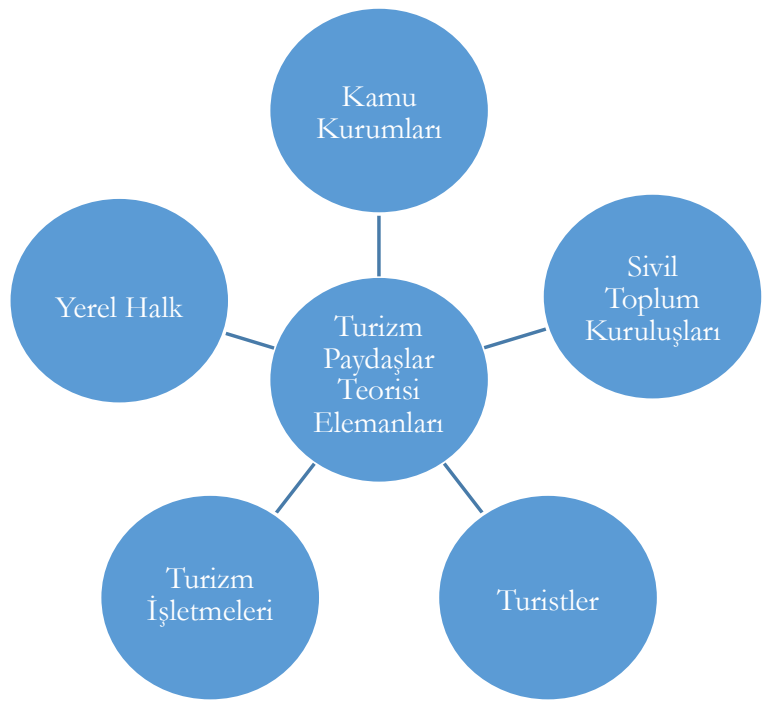

Şekil 1. Turiz̧m Paydaşlar Teorisi Elemanları (Kaynak: Baytok vd., 2017, s. 6)

\section{Turistik Ürünü Oluşturan Unsurlar ve Turizm Destinasyonu Ağrı İli}

Turistik ürün, turistlerin seyahatlerinin ilk başından en sonuna kadar geçen sürede ihtiyaçlarını karşılamak ve turistik arzı oluşturan faktörler tarafindan sunulan nesnel ve öznel değerlerin tamamıdır (Bahar ve Kozak, 2012; Akbaba, Güvenol ve Sağlam, 2019, s. 642). Bir şehrin turizm destinasyonu olabilmesi için turistik ürünü oluşturan özelliklere sahip olması gerekmektedir. Bunlar; çekicilik, ulaşılabilirlik, etkinlikler, turizm işletmeleri ve turizm imaj1 olarak sıralanabilir (Cömert, 2014, s. 65; Hacioğlu ve Avcikurt, 2008, s. 6).

Ağrı Destinasyonu, Doğu Anadolu Bölgesinde ve istatistikî Bölge Sınıflamasına göre Kuzeydoğu Anadolu Bölgesinde TRA Düzey 1 Bölgesinde, Kars, Ardahan, Iğdır ile birlikte TRA2 Kuzeydoğu Anadolu Alt bölgesinde bulunmaktadır. Ağrı destinasyonu denizden 1640 metre yükseklikte kurulmuştur. Yüzölçümü $11.376 \mathrm{~km}^{2}$ dir (Yazgan ve Kadanalı, 2012, s. 7). Ağn1 destinasyonunun turistik ürünlerini göz önüne alarak değerlendirme yapılabilir. Ağrı ili destinasyonun turistik ürün olarak değerlendirilmiştir. Kriterler belirtilen turistik ürünü oluşturan unsurlar göz önünde bulundurularak yapılmışır (Hacıoğlu ve Avc1kurt, 2008, s. 6):

Çekicilik: Turistin seyahat etmek istediği bir destinasyonu, başka bir destinasyona tercih etmesini etkileyen faktörlerdir. Çekicilik olgusu ulusal bazda olduğu gibi yerel nitelikte taşıyabilir. Ağrı ili bu konuda birçok turistik ürüne sahiptir. Başlıca turistik ürünler; İshakpaşa Sarayı, Ağrı Dağı, Urartu Kalesi, Ahmed-i 
Hani Türbesi, Nuh’un Gemisi, Balık Gölü, Diyadin Kaplıcaları, Doğubayazıt Sazlığı, Buz Mağaraları sayılabilir. Belirtilen her bir turistik ürünün önemli çekicilik yönü vardır.

İshakpaşa Sarayl: Destinasyonun önemli tarihi yapılarındandır. Kültür turizmi adına önemli bir çekiciliğe sahiptir. Topkapı Sarayı'ndan sonra Türkiye'nin ikinci büyük yapılar topluluğudur. Mimarisi ve görselliğiyle dikkat çeken yapı, Anadolu kültürel mirasının seçkin örneklerindendir. 1685 yılında yapımına Doğubayazıt Sancak Beyi Çolak Abdi Paşa tarafindan başlanılmış, daha sonra 1784'te 2. İshak Paşa Dönemi’nde bitirilmiştir. Dünyanın ilk kalorifer sistemine sahip olma özelliğini taşıyan yapıdır. Restorasyon sürecinde üzeri camla kaplanan Saray, Osmanlı İmparatorluğu'nun Lale Devri'ndeki önemli anıtsal eserlerindendir. Yapımı 99 yıl süren Saray, Saraydan öte bir külliyedir. Mimarisinde Osmanlı, Fars ve Selçuklu medeniyetlerinin ortak etkisi vardır (Karabulut ve Köksal, 2018, s. 209).

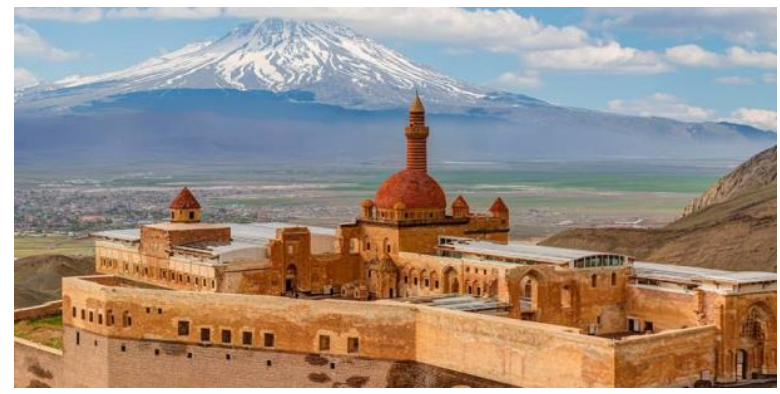

Resim 1. İshakpaşa Sarayı (Kaynak: www.renainsaat.com)

A ̆gr Dağg: Türkiye'nin en yüksek dağı (5137 m.) olan Ağn1 Dağ1 aynı zamanda Avrupa, Kafkaslar ve Ortadoğu'nun da ikinci büyük dağıdır. Ağrı Dağı Türkiye'nin en büyük milli parkıdır. Çeşitli flora ve faunaya sahiptir. Kış turizmi, Dağ turizmi (trekking) ve Özel ilgi turizmi açısından önemli bir çekici merkezdir. Ağrı Dağı'na çıkış ve iniş vakti en erken dört günde tamamlanmaktadır. En uygun çıkış zamanı Ağustos ve Eylül ayları arasındadır. Ağustos ayı çıkışlarında, $4500 \mathrm{~m}$. den sonra hava sıcaklığ $-10^{\circ} \mathrm{C}^{\prime}$ ye Eylül ayı çıkışlarında ise $-12^{\circ} \mathrm{C}$ ye kadar azalmaktadır. Ağrı Dağı'na tırmanan dağcıların bazıları oksijen yetersizliğine bağlı olarak kalp çarpıntısı, baş dönmesi ve baygınlık gibi rahatsızlıklardan dolayı $5000 \mathrm{~m}$. yükseklikten daha yukarı çıkamamaktadırlar (Kaya, 2016, s. 219).

Eski Bayazt Kalesi (Urartu Kalesi): Ağrı destinasyonunun önemli yapılarındandır. Kültür turizmi adına önemli çekiciliği bulunmaktadır. Doğubayazıt ilçesinin $7 \mathrm{~km}$. Güneydoğusunda (Belleburç Tepesi) denilen bir konumda, sarp bir kayalık üzerinde yükselen Eski Bayazıt Kalesi’nin (Urartu Kalesi) ilk olarak ne zaman ve kimler tarafindan yapıldığı hakkında bilgi bulunmamaktadır.Kalenin coğrafi konumu nedeniyle tarih boyunca önemli görevler üstlenmiştir (Karabulut ve Köksal, 2018, s. 209). Kale, konumu itibariyle Kafkaslardan gelen akınlara karşı bir üs olarak kullanılmışır. Kalenin bazı yerlerindeki duvar dokusu, mimari yapılar, kayaya oyulmuş olan Urartu kaya mezarları ve kalenin yakınlarında rastlanan yerleşim izleri Urartu dönemine ait olduğunu düşündürmektedir (Çetin, 2009, s. 23).

Ahmed-i Hani Türbesi: Ağrı destinasyonunda inanç turizm ürünleri açısından en önemli ürünlerden biridir. Ahmed-i Hani, 1651 yılında doğan ve ölüm tarihi hakkında kesin bir bilgi bulunmamaktadır. 17. yüzyılda yaşamış edebiyatçı, astronom, şair, tarihçi ve İslam âlimi Ahmed-i Hani'nin türbesinin yanında sonradan bir de cami yapılmıştır. En önemli eserleri, Mem û Zîn, (Mem ve Zin), Nûbihara Biçukan, (Küçüklerin Baharı), Eqîdeya Îmanê, (İman'ın Akidesi veya İnanç Risalesi). Türbe Doğubayazıt ilçesine 8 kilometre mesafede, İshak Paşa Sarayı'nın üst kısmında bulunmaktadır (Karabulut ve Köksal, 2019, s. 94; Geçit, 2013).

Nub'un Gemisi: Ağr1 destinasyonunda inanç turizm ürünleri açısından en önemli ürünlerden biridir. Doğubayazıt ilçesinin Üzzengili köyüne yakın bir noktada geminin siluetine rastlanmıştır. Müze alanı doğal sit alanıdır. Açık hava müzesi olarak ziyaret edilirken aynı zamanda alan da korunmaktadır (www.agri.ktb.gov.tr)

Ballk Gölï: Ağrı destinasyonunun doğa ve spor turizm ürünleri açısından en önemlilerinden biridir. Doğubayazıt ilçesinin $60 \mathrm{~km}$ kuzeybatısında bulunan balık gölü aynı zamanda Taşlıçay ilçesinin sınırları içerisinde yer almaktadır. Yaklaşık $34 \mathrm{~km}^{2}$ lik yüzölçümü ve 2241 metrelik su düzeyi yükseltisiyle Türkiye'nin yüksekte bulunan göllerinden biridir. Balık Gölü, Sinek Yaylasında bulunan ve en derin yeri $37 \mathrm{~m}$ olan bir lav set gölüdür. Alabalığı ile meşhur olan gölün suyu tatlıdır. Gölde alabalığın yanında sazan 
balığı da bulunmaktadır. Lakin balık gölünde yetişen alabalığın kış aylarında avlanması oldukça zordur. Çünkü rakımı yüksek olan göl, kış aylarında kalın bir buz tabakasıyla kaplanır (Karabulut ve Köksal, 2018).

Diyadin Kaphcalar: Ağr1 destinasyonunda sağllk ve termal turizm ürünleri açısından en önemli üründür. Ağrışehrinin Diyadin İlçesi’nde yer alan kaplıcalar, Diyadin ilçe merkezine $7 \mathrm{~km}$, Ağr1Doğubayazıt karayoluna ise $15 \mathrm{~km}$ uzaklıkta yer almaktadır. Eski dönemlerden bu yana termal tedavi amaciyla yararlanılan Köprü, Yılanl, Davut ve Tazekent termal tesislerinin cilt, deri, romatizmal ve eklem ağrılarına, solunum yolları, kadın hastalıkları ve mide ülseri rahatsızlıklarına iyi geldiği bilinmektedir (Zaman, Polat ve Özdemir, 2000, s. 349).

Doğubayažt Saح̨luğr: Ağr1 destinasyonunda kuş gözlemciliği ve endemik bitki gözlemciliği adına önemli bir turistik üründür. Doğubayazıt İlçesi ile Ağrı Dağı arasında kalan, Sazoba köyündeki bataklık alandan oluşan bölge Türkiye'nin önemli 100 kuş barınma alanı arasında yer almaktadır. Bu sazılı bölge, Balık Gölü'nden ve Tendürek Dağı'ndan gelen dere suyuyla beslenir. Yörede bulunan yaygın kuş türleri; çayır delicesi, erguvani, balıkçıl, boz ördek, pasbaş, turna, patka, kızılgaga ve kızılbacak olarak sayılabilir (Karabulut ve Köksal, 2018).

Buг. Mağaralar: Ağr1 destinasyonundamağara turizmi ürünleri açısından en önemli ürünlerinden biridir.Küçük Ağrı Dağı’nın güney eteğinde Hallaç köyü yakınlarında bulunan doğal bir anıt mağarasıdır. Mağara, uzun eksenli, elips şeklinde, yaklaşık 100 metre uzunluğunda, 50 metre genişliğinde, 8 metre derinliğinde bir turistik üründür. Mağaranın ağzı esas iç şekline nazaran biraz daha yukarıda kalmaktadır. Mağara içerisinde bazalt lavlar, kayalar ve bu kayaların üstünde saf ve temiz suların donmasiyla bir araya gelmiş buz tabakalarını görmek mümkündür (Yazgan ve Kadanalı, 2012, s. 8).

Ulaşılabilitlik: Yüksek çekicilik özelliklerine sahip destinasyonların, potansiyel hedef kitleye olan yakınlığı ve onlara cüzi maliyetlerle ulaşabilme imkânını sunar (Hacıoğlu ve Avcıkurt, 2008, s. 6). Bilhassa küresel rekabet sistemlerinde dünya nüfusunun yaşlandığını göz önüne alacak olursak destinasyona ulaşımın ne derece önemli olduğu görülecektir ve nüfus yoğunluğunun yüksek olduğu destinasyonlar ulaşımları kolay olduğu için kolay turist çekerler (Buhalis ve Michopoulou, 2011, s. 146; Cham, Lim, Sia, Cheah ve Ting, 2020; Clara, Simon, Noelia ve Barbara, 2020). Ağr1 ili ulaşılabilirlik açısından, Uluslararası Havalimanına sahip bir şehirdir ve İstanbul'dan uçuş yaklaşı iki saat sürmektedir. Karayoluyla İran ile sınır olmasının birçok avantajını yaşamaktadır. Yabancı turist çekme durumunu arttırmaktadır.

Turizm Íşletmeleri: Bir destinasyonun çekici olması veya ulaşılabilir olması tek başına yeterli olmamaktadır. Aynı zamanda o destinasyonda turistlerin yeme-içme, barınma, hediyelik eşya satın alma gibi ihtiyaçları da karşılanabilmelidir. Bu noktada turizm işletmelerine ihtiyaç olmaktadır (Şahin ve Ünver, 2015). Destinasyonun devamlılı̆ını sağlanabilmesi için işletmelerin olması ve destinasyonun korunmasında önemli rol oynamaktadırlar. Eğer sürdürülebilir turizm politikası güdülmez ise turizm işletmeleri zayıflar ve zamanla kaybolurlar (Chin, Day, Sydnor, Prokopy ve Cherkauer, 2019, s. 126). Ağrn ili turizm işletmelerine bakıldığında, 10 adet belediye belgeli konaklama işletmesi, 10 adet turizm işletme belgeli konaklama işletmesi bulunmaktadır. Turizm İşletme belgeli konaklama işletmelerinin 5 tanesi Doğubayazıt ilçesinde iken 5 tanesi de Ağrı şehir merkezindedir. Bunlardan 1 tanesi dört yıldızlı, 7 tanesi üç yıldızlı ve geri kalanlar ise iki yıldızlıdır. Şehirde A grubu 17 adet seyahat acentesi bulunmaktadır. Bunlardan 5 tanesi Ağrı şehir merkezinde, 5 tanesi Patnos ilçesinde, 5 tanesi Doğubayazıt ilçesinde, 2 tanesi de Eleşkirt ilçesinde bulunmaktadır (https://agri.ktb.gov.tr/)

Etkinlikler: Etkinliklere katılan turist sayısını en üst seviyeye çıkarmak amacıyla birincil veya ikincil turist çekicilikleri olarak etkinliklerin planlanması ve düzenlenmesi gerekmektedir (Getz, 1997, s. 16; Timur, Çevik ve Kıcır 2014, s. 58). Günümüzde turizm faaliyetlerini arttırmak için turisti destinasyonda tutmak gerekir ve bunu da etkinlik sayesinde yapmak mümkündür (Ziyadin, Koryagina, Grigoryan, Tovma ve Ismail, 2020; Lee, Martin, Hsieh ve Yu, 2020). Ağrı ili destinasyonuna etkinlikler boyutunda bakıldığında, her yıl yaz aylarında düzenlenen Balık gölü festivali ve Dünya Ağrllılar günü kutlanmaktadır. Dünya Ağrllılar günü her yılın 4 Nisanında Ağrı şehir merkezde kutlanmaktadır.

Turizm İmaji: Rekabet, ürünler yahut işletmeler arasında olduğu gibi, ülkeler ve destinasyonlar arasında da yaşanmaktadır. Turizm ürünü soyut ve birbiri ile benzer olduğu için destinasyonlar arası rekabet imajlar vasıtasıyla gerçekleşmektedir. Bir turizm destinasyonunun imajının olumlu yahut olumsuz olması, destinasyonun uluslararası arenadaki performansını ve diğer ülkelere nazaran rekabet avantajını yakından etkilemektedir (Ön Esen ve Bahar, 2019, s. 951). Bu sebeple rekabet gücünü yüksek tutabilmek 
için destinasyon yöneticilerinin doğru turizm planlaması yaparak turizm imajını ön plana çıkarmaları önemli bir husustur (Alrawadieh, Alrawadieh ve Kozak, 2019; Eid, El-Kassrawy ve Agag, 2019).

\section{Yöntem}

\section{Araştırmanın Amacı ve Önemi}

Araștırmanın amacı, Ağn ilinin alternatif turizm potansiyelini ve yerel paydaşların alternatif turizm hakkındaki görüşlerini ortaya çıkarmaktır. Bu amaç doğrultusunda Ağrı ilinin alternatif turizm potansiyeli ve paydaşlara yönelik katkılar araştırılmıştır. Araştırma Ağrı özelinde yapılması ve yerel paydaşların alternatif turizme bakış açısını ortaya koyması sebebiyle önem taşımaktadır. Ağıı ilinde alternatif turizme yönelik çalışmaların henüz yapılmamış olması çalışmayı özgün ve geleceğe ışık tutan bir çalısma olmasını sağlayacaktır.

\section{Araştırma Verilerinin Toplanması}

Araştırma verileri 01 Eylül 2020-01 Ekim 2020 tarihleri arasında Ağr1 ilinde toplanmıştır. Veriler, konuya ilgisi olan ve yöreye hâkim olan bireylerden görüşme yoluyla toplanmıştır. Bu sebeple amaçlı/yargısal örneklem kullanılmıştır. Amaçlı örneklem, zengin bilgiye sahip olduğu düşünülen durumların derinlemesine çalışılmasına imkân sağlar (Yıldırım ve Şimşek, 2008, s. 107). Evrenin net bir biçimde temsili için her ilçeden en az 1 kişi olacak şekilde veriler elde edilmiştir. Araştırmaya dâhil edilen örneklemden randevular alınarak çalışma konusu ve amacı hakkında bir takım bilgiler verilmiştir. Görüşme sırasında ses kayıtları ve tutulan notlarla veriler Word dosyasında metin halinde hazırlanmıştır. Tüm görüşmeler katılımcıların izniyle yapılmıştır. Araştırma kapsamında 16 kişiyle görüşülmüştür. Odak grup görüşmeleri için 12 sayısı yeterli olmaktadır yapılan görüşmenin derinliği arttıkça sayıda artmaktadır derinlemesine görüşmeler için ise sayının 30'a kadar yükselmesinde bir sorun görülmemektedir. Yaklaşık 30 olması yeterli olabilmektedir (Başkale, 2016, s. 27). Araştırmada kapsamında görüşme sayısı bu noktada yeterli görülmektedir. Görüşmelerin ortalama süresi 30-40 dakika arasındadır.

\section{Araştırma Yöntemi}

Araştırma kapsamında nitel araştırma yöntemlerinden görüşme tekniği kullanılmıştır. Araştırmada derinlemesine görüşme ile konuya ve yöreye dair bilgileri olan paydaşlardan görüşmeler sağlanmıştır. Derinlemesine görüşme katılımcılarla bire bir yapılır ve bir katılımcı ile olan görüşme bitmeden diğer bireyle görüşme yapılmamalıdır. Katılımcıların, inanç, tutum ve güdülerini öğrenmek amacıyla bir sınırlama olmaksızın eleştiri ve görüşlere varmaktır (Nakip, 2013, s. 123). İlgili literatür incelenerek konu hakkında daha önce yapılan mülakatlardan yola çıkılarak yarı-yapılandırılmış sorular hazırlanmıştır. Araştırmada, görüşme tekniğinin kullanılma sebebi, araştırma için derinlemesine bilgi toplamaktır. Uzman kişilerin çalışmada tercih edilme nedeni yöre ile ilgili alternatif turizm noktasında noksansız bilgi sahibi olmaktır.

Araştırmada betimsel analiz yönteminden yararlanılmıştur. Betimsel analiz, doğrudan bir konunun resmedilmesi, tanımlanabilmesini ve açıklanabilmesini amaçlayan bir yöntemdir. Bu noktada sorulardan elde edilen verileri desteklemek üzere görüşmelerden doğrudan doğruya alıntılar alınmaktadır (Ekiz, 2009, s. 76). Araştırma sınırllıkları ise zaman probleminin olması araştırmacıların mesleki durumlarından kaynaklı olarak veri toplama da zaman sorununun olması. İkinci olan husus ise Ağrı ilinin yüz ölçüm olarak geniş olması ve ilçeler arasındaki uzaklık sebebiyle araştırmacılara maddi konuda sınırlılık oluşturmasıdır.

Araştırmada iki bölüm oluşmaktadır. Birinci bölümde katılımcıların demografik özelliklerine yönelik bilgiler yer alırken ikinci bölümde ise katılımcıların alternatif turizm potansiyeline yönelik sorular yer almaktadır. Araştırma soruları, alan uzmanları ve daha önce konuyla ilgili yapılan çalışmalarda yer alan sorulardan meydana gelmiştir. Her sorunun kaynağı karşısında belirtilmiştir. Araştırmaya katılan katılımcılara yönelik yarı-yapılandırılmıss sorular aşağıdaki gibidir; 
Tablo 1. Araştırma Sorular ve Uyarlandĭğ Callsmalar

\begin{tabular}{ll}
\hline Araştırma Sorusu & Kaynak \\
\hline 1) Alternatif turizm denilince aklınıza neler gelmektedir? & Akyürek, Özdemir ve Çeken, 2018 \\
2) Sizce alternatif turizm ürünlerine yeterince gereken önem veriliyor mu? & Zengin ve Şeyhanlıoglu, 2019 \\
3)Alternatif turizmin yöre ekonomisine katkıları olduğunu, elde edilen geliri arttırdığını & Zengin ve Şeyhanlıoğlu, 2019 \\
düşünüyor musunuz? & Zengin ve Şeyhanlıŏllu, 2019 \\
4) Alternatif turizmin yöreye sosyal etkileri nelerdir konu hakkında düşünceleriniz? & Zengin ve Şeyhanlıoğlu, 2019 \\
5) Yöredeki turizmin gelişimine bağlı olarak alt yapı hizmetlerinin (yol, elektrik, su vs.) de & Akyürek vd., 2018 \\
geliştĭgine inanıyor musunuz? & Akyürek vd., 2018 \\
6) Alternatif turizmin gelişmesinde konaklama tesislerinin durumu sizce nedir? & Akyürek vd., 2018 \\
7) Alternatif turizm konusunda girişimcilik düzeyi hangi noktadadır? & Akyürek vd., 2018 \\
8) Turistlerin yöreye gelmesinden rahatsızlık duyuyor musunuz? & Zengin ve Şeyhanlığlu, 2019 \\
9) Alternatif turizmin yöredeki el sanatlarına ve yöresel ürünlere olumlu olarak etkileri oldu mu? \\
10) Ağri ilinde turizmin gelişebilmesi için neler yapılmalıdır? & \\
\hline
\end{tabular}

\section{Bulgular}

\section{Katılımcılara İlişkin Demografik Bulgular}

Tablo 2'de görüldüğü üzere araştırma çerçevesinde görüşme yapılan katılımcıların büyük çoğunluğu erkeklerden oluşmaktadır. Bu durumun sebebi, şehrin sosyal yapısından kaynaklanmaktadır. Cinsiyete göre katılımcı sayısı, 4 kadın ve 12 erkek bireyden oluşmaktadır. Katılımcıların eğitim durumları değerlendirildiğinde, 6 katılımcı lisans mezunu iken, 4 katılımcı lise mezunu, 3 katılımcının lisansüstü, 2 katılımcının ön lisans mezunu, 1 katılımcının ise ilköğretim mezunu olduğu ortaya çıkmaktadır. Bu eğitim seviyesi de göstermektedir ki; şehrin her eğitim seviyesindeki bireylerden veriler toplanmıştır. Görüşmeler sonucunda katıllımciların medeni durumlarının 13 kişi ile çoğunluğunun evli oldukları tespit edilmiştir. Diğer taraftan katılımcı yaşadıkları ilçe olarak 7 kişi Doğubayazıt iken, 2 kişi Patnos, 2 kişi Ağrı merkez, 1'er kişide Taşlıçay, Hamur, Eleşkirt, Diyadin, Tutak ilçelerinde yaşamaktadırlar. Buna göre örneklem grubu olarak şehrin temsilini doğru bir şekilde yapmak adına Ağrı ilinin tüm ilçelerinden katılımcılarla görüşme sağlanmıştır. Katılımcıların görev durumları ele alındığında, 5 kişinin Kamu personeli, 3 kişinin STK temsilcisi, 2 kişinin güvenlik görevlisi, 2 kişinin girişimci, 1'er kişinin ev hanımı, gazeteci, aşçı, avukat oldukları sonucuna varılmışır. Buna göre şehri oluşturan tüm yerel paydaşlardan veriler toplandığ1 görülmektedir.

Tablo 2. Katıllmolara Dair Demografik Bilgiler

\begin{tabular}{|c|c|c|c|c|c|}
\hline Katılımcilar & Cinsiyet & Eğitim Durumu & $\begin{array}{l}\text { Medeni } \\
\text { Durumu }\end{array}$ & Yaşadığınız İlçe & Görev Durumu \\
\hline Katılımc1 1 & Kadin & Lisans & Evli & Doğubayazıt & Kamu Personeli \\
\hline Katılımc1 2 & Erkek & Lisansüstü & Evli & Doğubayazıt & Kamu Personeli \\
\hline Katılımc1 3 & Kadın & Lisansüstü & Evli & Doğubayazıt & Kamu Personeli \\
\hline Katılımc1 4 & Erkek & Lisansüstü & Bekâr & Doğubayazıt & Kamu Personeli \\
\hline Katılımcı 5 & Erkek & Lisans & Evli & Doğubayazıt & Kamu Personeli \\
\hline Katılımc1 6 & Kadin & Lise & Evli & Taşliçay & Ev Hanımı \\
\hline Katılımc1 7 & Erkek & Lise & Evli & Hamur & Güvenlik \\
\hline Katılımc1 8 & Erkek & Ön Lisans & Evli & Eleşkirt & Güvenlik \\
\hline Katılımc1 9 & Erkek & Lise & Evli & Patnos & Girişimci \\
\hline Katılimc1 10 & Erkek & Lisans & Evli & Ağrı Merkez & STK Temsilcisi \\
\hline Katılımcı 11 & Kadin & Lisans & Bekâr & Tutak & Gazeteci \\
\hline Katılımcı 12 & Erkek & İlköğretim & Bekâr & Diyadin & Aşç1 \\
\hline Katılımcı 13 & Erkek & Lise & Bekâr & Ağrı Merkez & Girişimci \\
\hline Katılımcı 14 & Erkek & Lisans & Evli & Doğubayazıt & Avukat \\
\hline Katılımcı 15 & Erkek & Lisans & Evli & Patnos & STK Temsilcisi \\
\hline Katılımc1 16 & Erkek & Ön Lisans & Evli & Doğubayazıt & STK Temsilcisi \\
\hline
\end{tabular}

\section{Yerel Paydaşlara İlişkin Bulgular}

Katıllımcılara ilk olarak “alternatif turizm hakkında bilgileri” sorulmuştur. Görüşmelerden elde edilen bulgulara göre, yerel halkın alternatif turizm hakkında bilgi sahibi olduğu, hatta şehrin alternatif turizme yönelik girişimleri hakkında kapsamlı bir şekilde bilgi verdikleri görülmüştür. Bu bağlamda bazı katılımcıların görüşlerine yer verilmektedir. 
"Alternatif olan turizm türleridir. Mesela kers turizmi, spor turizmi, inanç turizmi, gençlik turizmi, kersal turizm diyebiliriæ: Gegenlerde televi氵zyonda bununla ilgili bir programa denk geldim ve Türkiye turizm konusunda çok zengin bir ülkedir”. (Katılimo 6).

"Benim için deniz turizminin dışında kalan hepsi alternatif turizme girer mesela kış turizmi, dăg turizmi, kamp-karavan turizmi hepsi bunun içindedir." (Katıllmo 9).

"Ben siz̨i mülakata kabul etmeden önce konuyla ilgili araștormalar yaptum. Kültür turizmi, gastronomi turiz̧mi, golf turizmi aklma gelen konular. Tabi ki bunlarla da yetinmeyecek derece de çok alternatif turizm çeşidi vardrr." (Katllimor 11).

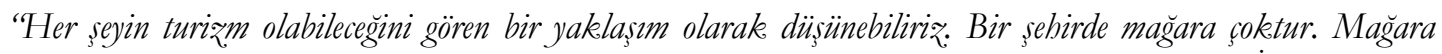
turizmi dersiniz. Bir şebirde tarm arazisi çoktur. Tarm turizmi dersiniz. Türbe çoktur. Inanc turizmi dersini:" (Katullmo 13).

Katıllımclara sorulan diğer bir soruda "alternatif turizm ürünlerine yeterince gereken önem verilmesine" yönelik sorulmuştur. Görüşmelerden elde edilen bulgulara göre, alternatif turizm ürünlerine gereken önemin yeni verilmeye başlandığı kanısındadır. Daha önceleri turizm için potansiyel barındıran Ağrı iline yeterince önem verilmediğini lakin geleceğe dair umutların olduğu ve projeler hazırlandığı dile getirilmiştir. Bu bağlamda bazı katılımcıların görüşlerine yer verilmektedir.

"Son zamanlarda verilmeye basslandl. Cünkü görüyorum ki; İshakpasa sarayında defileler yapilyyor, bunu gerçeklesstirmek kolay bir durum değil. Bir sürü manken, ünlü geldi. Bu demek oluyor ki gelecekte yatrrm gelecektir." (Katılima 4).

"2-3 ynl öncesi olsa ben önem verilmiyor derim. Korona virüs etkilese de baya gelen var. Turizm etkinlikleri artth

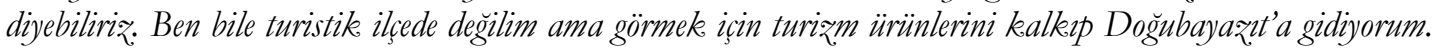

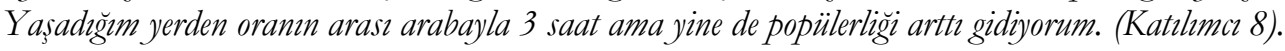

"Öncelikle doğrusu biə̨im turistik ürünlerimiz genellikle Doğubayą?t ve Diyadin ilçelerinde yoğundur. Projeler toplantilar olmaktadrr. Gesenlerde üniversitede valilike öncüliügünde turiz̨m paydasslar toplantist yapılda. Bu gösteriyor ki gerekli önem verilmektedir." (Katillma 10).

"Bence yeni yeni gereken önem veriliyor. Cünkï unutmaymız ki turizm bacasız sanayi ve para kazandrryor kimse hayır diyemez: Türkize ekonomik olarak turižmden geçimini sağglyor. Daba da önem verilmeli doğru yatrim gerekli." (Katulimo 14).

Katılımcılara yöneltilen üçüncü soruda "alternatif turizmin yöre ekonomisine katkısına” yönelik sorulmuştur. Görüşmelerden elde edilen bulgulara göre, yerel halk turizmin ekonomik katkılarının olduğunu hatta yeterli turist çekemediklerini turist attırllırsa halkın her kesiminin bu noktada faydalanacağını belirtmektedir. Turist gittiği her şehirde para bırakır düşüncesi hâkimdir. Bu bağlamda bazı katılımcıların görüşlerine yer verilmektedir.

"Yöre ekonomisine ve yöre de yasayan insanlarn, turistik geąilere bakuss açsı ve turistlere gösterdikleri ilgi ve alakann artmasidir. Buna bağh olarak yöre ekonomisine bem maddi hem de manevi katkisl da bulunmaktadrr." (Katılimcr 1).

"Mevcut yaşadiğrmı salgin sebebiyle büyük bir dïşüsün olduğu aşikâr. Tabi ki yöre ekonomisine katkısı var. Turist demek gelir demek. Yaşadrğgm yörenin tanttmmin yeterli olduğunu ve bu anlamda yatrrmlarn yapildiğgm düsï̈nmüyorum. Yani çekicilike var ama hem de fazlasylla ama bunu işlemekte çok eksiklik var. En başında güvenliğin sağlanması lazım. Bunlar sağlanırsa gelirde artar.” (Katıllmoı 3).

"Ben gerçekçi olarak düsïnüyorum. Sehrin turizm potansiyeli var ama turist cekemiyoruz. Evet, geliri arttrrer alternatif turizm ama biz. bunu yapamiyoruz. Bu konuda attlim göstermeliyiz. Ağrn dağg, Nuh'un gemisi, İshakpassa sarayn, Urartu kalesi, keşişin bahçesi, hani baba türbesi ile mubtesem zenginliklere sabibir:" (Katılima 5).

"Tabi ki ekonomiye turistin her daim katkısı olacakttr. Örneğin; Ağrn sebrine gelen bir kişi çay bahcesine gider, lokantaya gider, WC kullansa bile para birakiyor. Ağgr șehri paym alyor. Sadece biraz daha profesyonelleșme gösterilmelidir." (Katılimo 7).

Katıllımcılara yöneltilen dördüncü soruda “alternatif turizmin yörenin sosyal yaşamına etkilerine” yönelik sorulmuştur. Görüşmelerden elde edilen bulgulara göre, yerel halk alternatif turizmin sosyal yaşamı hareketlendireceğini hatta kültürel ve sanatsal faaliyetlerin şehirde artacağını düşünmektedir. 
Turist demek sosyal yaşamın hareketlenmesi demektir fikri ön plandadır. Bu bağlamda bazı katılımcıların görüşlerine yer verilmektedir.

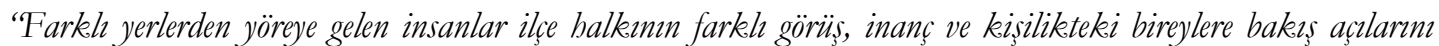
değisstirebilir. Bunun yan sira ekonomik olarak alternatif turizmden gelir elde etmek isteyen yöre balks bir takum sosyal ve eğitsel çalssmalar içerisine girerek kişilike gelisimine katker sağlayabilir. Örneğin yörede var olan turizm kaynaklarna bağh olarak gelen turistlerden maddi kazanc elde etmek isteyen yöre halkindan olan kadinlarn, hal dokumachlğg alanmnda alacağz eğitimle beraber satıs yaparak gelir elde etmek. istemesi. Bu gibi durumlar turizmin ekonomik işlevine bağh olarak sosyalleșmeye olanak sağlayabilir.” (Katıllmoı 2).

"Şebri sosyolojik olarak gelistiven sey turizmdir. Turizm demek barss, güven ve buzur demektir. Cünkü milletiniz ne olursa olsun aym ortamdasmi. Bence turizm olmazsa şehir sosyal olarak gelismesi zayflar. Örneğin; Antalya ile Ağrn ayn mı? Asla değil. Sebebi turizm.” (Katılımc 12).

"Sosyal olarak birçok etkisi olur. Bakınz. Ağr ili gibi mahalli șehirlerde kültür kapalh olabiliyor. Yani insanlarn sinurlar daha net oluyor ama turizm olsa daha sosyal ortamm yülksek olduğu bir yer haline geliriz:" (Katılima 15).

"Şehir sosyal olarak gelisme gösterir. Birçok etkinlik ve kaynasma merkezi haline getirebiliriæ. Şehir buna müsait sebebi ise Ağrnmn dişardda nüfusu çok yükesek. Ankara, İstanbul vs. gibi şebirlerde çok. Ağrnlu var. Yani buradaki insanlar görmüs yasamıs bu sebeple turizmin sosyal durumlar bizi beklenen seviyeye getirecektir. Daha güzel bir Ağn ili için el ele vermeliyiz. Bunu gönülden yapmaliyız: Fizịki olarak zaten Covid-19 var." (Katillimo 16).

Katılımcılara yöneltilen beşinci soruda "Yöredeki turizmin gelişimine bağl1 olarak alt yap1 hizmetlerinin gelişimine" yönelik sorulmuştur. Görüşmelerden elde edilen bulgulara göre, şehrin genelinde alt yapı problemlerinin olduğunu gelişimin birkaç yıldır olduğu düşüncelerine varılmıştır. Şehir de en büyük sorunun elektrik kesintisi noktasında yaşandığını ve il merkezinin daha iyi durumda olduğu dile getirilmiştir. Bu bağlamda bazı katılımcıların görüşlerine yer verilmektedir.

'Ben Tashlçay'da sorun olduğunu biliyorum. Ama gesen gün eşimle gezmeye Doğubayazt'a Alssveris merkezine gittim. Elbise falan alacaktnk. Alşsveriş merkęinde WC kapali sebebi şehrin kanalizasyon șebekesi sorunlu dediler. Yollar toz toprak yani bir kişi astım olur. Ben turist olsam bende gelmem bu alt yapiya." (Katılima 6).

"Patnos için konuşmak gerekirse yok zayıf. Ayn durum Doğubayazut içinde geçerlidir. Turistike ürünler orada var lakin gel gör ki toz toprak sok. Elektrik sik gidip geliyor bu durum çok can sılemaktadrr.” (Katilimo 9).

"Turizm gelisirse yol, su, elektrikte gelisir. Elektrik kesintisi çok olmaktadir burada. Yol ve su için gayet normal bir durum var. Anadolu'da olmak arthk kötü bir talih değgll. Çünkü teknolojizle her yere bağlanirsmi: O yüzden gelişim şart.” (Katılimo 11).

"Bence Ağrıda yapılacak şok iș var. En önemlisi de alt yapıdrr. Cok zayrf bir durumdayı önemli bir gelisim olursa da turizm sebebiyle olur. Çünkü turist demek alt yapr ve üst yapr demektir. Şebir merkezi bu noktada ilçelere göre bir iki adim öndedir. Alt yapu olmadan kimse rahat edemez:" (Katılimo 14).

Katılımcılara yöneltilen altıncı soruda "alternatif turizmin gelişmesinde konaklama tesislerinin durumuna" yönelik sorulmuştur. Görüşmelerden elde edilen bulgulara göre, katıllimcılar tesislerin durumunu zayıf bulmaktadır. Genel olarak bir tadilat yöntemine gidilmesi gerektiğini hatta yıldız artırımı için kaliteli hizmet verilmesi gerektiğini dile getirmişlerdir. Ayrıca yerel paydaşlar yıldızı yüksek otellerin yoksunluğundan şikâyet etmektedirler. Bu bağlamda bazı katıllımcıların görüşlerine yer verilmektedir.

"Konaklama tesislerinin ibtiyacı karşılamada yeterli olmadığgn düsünüyorum. Ayrnca mevcut işletmelerin bijjenik ve gelismis olamadiğm düssünüyorum." (Katıllmor 1).

"Doğubayazt illgesinde yeterince ibtiyaca yönelik uygun konsept ve kalitede otel ve konaklama imkan olmadiğm düsünüyorum. Var olan konaklama imkânlarmm ise bakımsız, eski ve kendini yenileyemeyen işletmeler olduğn gö̈zükmektedir.” (Katılimcı 2).

"Bana göre yetersiz bir durum var. Cünkü turist yetersizlïgi vard. Birde üzerine korona gelince hepten kesildi. Konaklama işletmeleri için girişimcilere çok is düsï̈or gelişim şart. Hele Doğubayazıt'ta dürgün otel yok. Maalesef gelisim olmazsa olmaæ:” (Katilimo 11). 


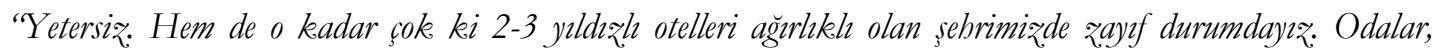
yataklar gerçekten kaliteden uzake bir vaziyetteyiz. Kesinlikle acilen girișimciler otelleri düzene tadilata almah. Şabsi fikrim.” (Katılimcı 15).

Katılımcılara yöneltilen yedinci soruda "alternatif turizm konusundaki girişimcilik durumuna" yönelik sorulmuştur. Görüşmelerden elde edilen bulgulara göre, katıllmcılar genel olarak girişimcilik düzeyini zayıf bulmuş olup zamanla gelişeceği noktasında görüşler belirtmişlerdir. Bilhassa şehrin zenginli ve varlıklı ailelerinin şehre yatırım yapması yerine büyükşehirlere veya çevre illere yatırım yaptıklarından duydukları rahatsızlığı dile getirmişlerdir. Bu bağlamda bazı katılımcıların görüşlerine yer verilmektedir.

"Şuan durum kötü çünkü turizme para yaturmak riskli Ağrn şehrine gelen turist günübirlik turlarla gelip gidiyor. Turist rebberi ayarlamaz̧san yandin. Ben zamana ibtiyaç var diyorum. Çünkï Ağr ili bakir bir yer ve zamanla gelisecektir." (Katzlima 4).

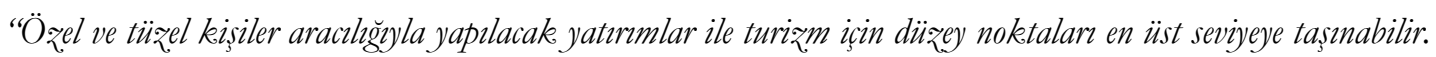

Yeter ki bu güzel şehrin eksiklerini görüp işletmeler kursunlar ve insanlar evlerinin geşimini rahat yapsinlar." (Katılima 5).

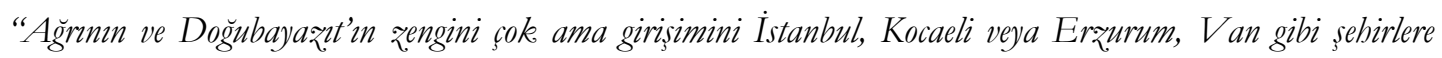
yapmaktadrlar. Buralar ne olacak merak ediyorum. Ekonomik gelisme kaydetmek için elzemdir yatrrm. Şehrin büyü̈kleri bu ișe bir el atmahddr. Gerekirse Ağrllalar gününde hepsini toplayn yardom edin denilmeli. Mesela Ağrll büyük ünlüler var. Bunlara pamuk eller ceplere denilmelidir. Gelin işletme kurun demeliyi:" (Katılimo 10).

"Zamanla düzelecektir. Şuanda zayrf çünkü girişimci yatırmdan korkuyor. Işsletmecinin mantĭğ şudur. 3 verirsem en az 5 kazanaym. O nedenle girisimci çekiniyor." (Kathlimcr 12).

Katılımcılara yöneltilen sekizinci soruda "turistlerin yöreye gelmesinden rahatsızlık duyma durumlarına” yönelik sorulmuştur. Görüşmelerden elde edilen bulgulara göre, katıllımcılar turistlerin gelmesini istediklerini yapacakları misafirperverlikten onur duyacaklarını hatta sürekli olarak gelmelerini istediklerini belirtmişlerdir. Bu bağlamda bazı katılımcıların görüşlerine yer verilmektedir.

"Turistin zarar olmuyor. Bence turizm olunca herkes mutlu olur. Turizm tüm güzellikler için var olan bir

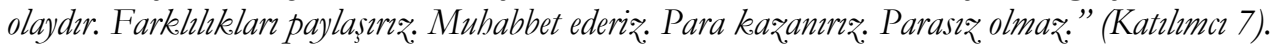

"Bence gelmemesinden rahatsızllk duyuyorum. Hep turist olsun ki. Turist demek para demektir. Zamanla

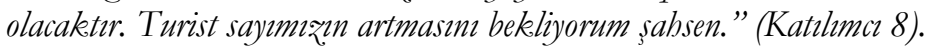

"Yeter ki gelsinler dört gözle bekliyoruz: Çünkü ekonomi için kalkenma için turizm şarttur. Her daim beklentim yükesektir. Yabanc gelince biz, bürmet duynyoruz. Turistin bize zarar olmaz:" (Katnlmon 13).

'Turist gelsin diye çabalyoruz: Gelmese daha nice olur halimiz. Az da olsa geliyor. Iran'dan kapr kapalı idi korona' dan dolayz şimdide can korkusu salgindan kimse seyahat etmiyor. Ne olacak bakalim. Salgindan sonra eski kalabalı, günlere döneceğimiz̨i umuyorum. (Katılmaı 16).

Katılımcılara yönelik dokuzuncu soruda "alternatif turizmin yöredeki el sanatlarına ve yöresel ürünlere katkılarına” yönelik sorulmuştur. Görüşmelerden elde edilen bulgulara göre, katıllımcılar alternatif turizm sayesinde el sanatları ürünleri, halılar, sanat eşyaları özellikle ebru, tezhip ve geleneksel Türk sanatı ürünlerinin satışının olduğu hatta satış yapan merkezlerin para kazandıkları ifade edilmiştir. Bu bağlamda bazı katılımcıların görüşlerine yer verilmektedir.

"Tabii ki mutlaka oluyor. Yöresel el sanatlarmm turistler tarafindan satm almasi ve kendi bölgelerine götürmeleri, bediye etmeleri, yörenin el sanatlar tantımı açısından oldukeça önemlidir.” (Katılımcı 4).

"Tabi ki olur. Ağr merkezde kadunlar birleșip el balısı dükkâan açmışlar. Çok kazanuyorlar. Bu turižmi canlandrryor. Müthis bir durum bana göre. Kitre bebek satsslar falanda iyi."(Katzlima 9).

'Bence olur. Yörede birçok el sanatı ürünü var ve dükkânlar hem Doğnbayažnt'ta hem de Ağr merkezde mevcuttur. Gelen turist herkese fayda sağlar. Firnncyya, ayak.kabicyya, otele, markete herkese o nedenle cok el sanatı işi yapanlarda kazanir." (Katulima 10).

"Kesinlikle olmaktadrr. Ben mesela süs halıs aldm merkęden ve dükkeânlara gittig̈imde dükkânlar dolu idi. Yerli turist allsverişs seviyor gördiügüm kadaryla." (Katıllmo 14). 
Katılımcılara yönelik sorulan onuncu soruda "şehirde turizmin gelişmesi konusunda ne yapılmalı" hususunda sorulmuştur. Görüşmelerden elde edilen bulgulara göre, tanıtımın, imaj çalışmalarının, kaliteli turizm işletmelerinin, ulaşılabilirliğin, medya kullanımının, etkinliklerin ve çekiciliklerin arttırılması noktasında üzerinde durulması gerektiğinin vurgusu yapılmıştır. Şehrin eksikliklerinin giderilmesi ve yerel paydaşların sürekli toplantılar düzenlemesi gerektiği hususunda görüşler ifade edilmiştir. Bu bağlamda bazı katılımcıların görüşlerine yer verilmektedir.

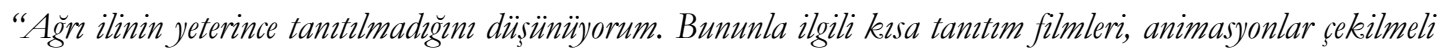
ve Türkije ve dünyaya ilin görülmeye değer olan yerlerinin tamitumlar yapılmalddr. Bununla beraber il genelinde gerekli alt yapı hizmetleri yapıml, konaklama tesislerinin nitelï̈i artturlmal, il genelinde turlar düzenlenmeli, özellikle gençler açsindan çekici gelebilecek etkinliklerin bulunduğu festivaller düzenlenmeli, ilin güvenlik ile ilgili bir probleminin olmadĭg konusunda insanlar bilgilendirilmeli, yöre balke turizmin önemi konusunda bilgilendirilmelidir" (Katulima 1).

"Bir sanatç olarak değerlendirdiğimde müze kurulması, yapulan sanatsal faaliyetlerin sergilenmesi ve bu sanatsal faaliyetlerin yöreyle bağdastorlması (mesela Mem ü Zin adh eser minyatür sanatiyla görsel anlamda yapulhp

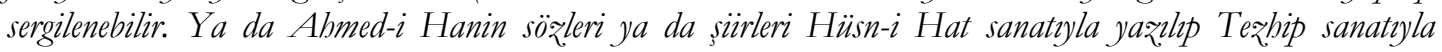
süslenip koleksiyon olusturulabilir ki bu konu bakkinda proje yazmaktaynm. Konaklamada alternatif otellerin olması, güvenliğin iyi olduğu bakkeında, daba çok yatırmlarn yapılması vs..." (Katıllmoı 3).

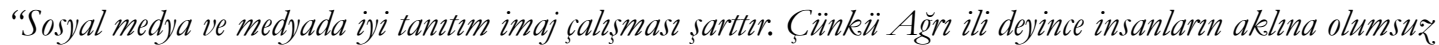
durumlar geliyor o nedenle elimizden geleni yapmak zorundayı: Tamtım șart. Düs̈̈̈nün alternatif turizm ürünlerini; İshakpassa Sarayı, Hani Baba Türbesi, Ağrn Dă̆ı Milli Parkı, Balık Gölï, Diyadin Kaplıcalarn, Keşişin Bahçesi, Urartu Kalesi, Nub'un Gemisi ve daba niceleri..." (Katıllmo 10).

"Bence yerel değil ama ulusal çapta gazetecilerin davet edilmesi şehri tanttmu yapmalar gerekir. Yani medya duruma el atmah ve çok değissik fikirlerle güzel bir Ağr șehri olmal. Herkes bunun için uğrașmal. Siz

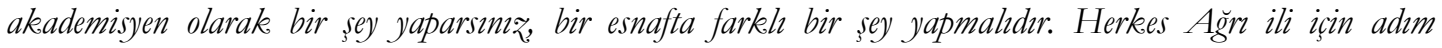
atmalidr." (Katılima 11).

\section{Tartışma, Sonuç ve Öneriler}

Ağrı destinasyonu alternatif turizm kaynakları açısından zengin kaynaklara sahiptir. Ağrı destinasyonu alternatif turizm bakımından oldukça zengin olmasına rağmen tanıtım, imaj, turizm planlaması ve turizm bilinci konusunda zayıflıklar olduğu söylenebilir. Yapılan araştırma da elde edilen sonuçlara göre, yerel paydaşlarnn alternatif turizm konusuna ilgili oldukları hatta alternatif turizm türlerini sırasıyla sayabildikleri gözlenmiştir. Bu sonuç destinasyonun alternatif turizm geleceği noktasında olumlu gelişmelere işaret etmektedir. Yerel paydaşlardan elde edilen diğer bir sonuçta alternatif turizme gereken önemin verilip verilmediğine yönelik olmuştur. Yerel paydaşların alternatif turizmin yeni gelişmeye başlandığını hatta bununla ilgili projeler toplantıların arttığı ve girişimlerin arttığı görülmüştür. Bu nokta da alternatif turizm faaliyetlerinin gelecek yıllarda daha da artacağı ve şehre katkı sağlayacağı sonucuna ulaşılmıştır.

Alternatif turizmin yöreye ekonomik katkıları konusunda, yerel paydaşların beklentilerinin yüksek olduğu görülmektedir. Eğer beklenilen turisti destinasyona çekip hatta bir gece konaklaması sağlanırsa yerel ekonominin kalkınacağı düşüncesi hâkimdir. Ekonomik katkılara söylenecek başka bir şey ise turist nimettir bakış açısıdır. Gelen turist para kazandırır görüşü bireyleri harekete geçirmek için önemli motivasyon kaynağı olduğu görülmektedir. Alternatif turizmin yöreye sosyal katkıları konusunda, yerel paydaşlar sosyal olarak gelişimin olabilmesi için turizmin olması gerektiği sonucunu ortaya koymuşlardır. Turistin sosyal yaşamı ve destinasyonu hareketlendireceği görüşü ön plandadır.

Turizmin gelişmesine bağlı olarak, alt yapı ile ilgili olan düşüncelerde ise gelişimin son birkaç yıl olduğu fakat alt yapının zayıf elektrik kesintilerinin çok olduğu sonucuna varılmıştır. Yerel paydaşlar, eğer turizmin etkisi yüksek olursa gelecek adına umutlu olduklarını dile getirmişlerdir. Tesisleşme konusunda, yerel paydaşlar Ağrı destinasyonunu zayıf bulmuşlardır. Özellikle konaklama işletmeleri konusunda birçok eksiğin dile getirildiği sonucuna ulaşılmışır. Hizmet kalitesi konusunda bir adet 4 yıldızlı otelin olduğu ve daha kaliteli, yıldızlı, kurumsal otellerin açlması gerektiği dile getirilmiştir. Yerel paydaşlar, girişimcilik düzeyi konusunda Ağr1 destinasyonunun zayıf olduğunu dile getirmişlerdir. Ağr1 ili zenginlerinin veya girişimcilik kabiliyeti yüksek kişilerin yatırımı büyükşehirlere yaptıkları sonucuna ulaşılmıştır.

Ağrı ilinin yerel paydaşlarının turistlere olumlu bakış açısı beslediklerini ve her daim turist gelmesi gerektiği dile getirilmiştir. Turistlerin her zaman gelmeleri yerel paydaşları mutlu edeceği ve gelen turistin 
bir daha gelmesi için çabalayacakları konusunda görüşler beyan etmişlerdir. Yerel paydaşların, turizmin el sanatlarına etkisinin olumlu olduğunu dile getirmişlerdir. Ekonomik olarak destinasyondaki yerel paydaşlara olumlu etkisi olduğu sonucuna ulaşılmıştır. Şehrin gelişmesi noktasında yerel paydaşlar genel olarak tanıtım ve imaj çalışmalarına ağırlık verilmesi konusunda görüşler ifade etmişleridir.

Araştırmamızda Ağrı destinasyonunun alternatif turizm ürünlerinin zengin olduğu konusundaki sonuçlarla (Zaman vd., 2000; Çetin, 2009; Yazgan ve Kadanalı, 2012; Kaya, 2016; Karabulut ve Köksal, 2018; Karabulut ve Köksal, 2019) benzerlik göstermiştir. Destinasyon imajı, destinasyon tanıtımı önemi konusunda (Alrawadieh vd., 2019; Zengin ve Şeyhanlıoğlu, 2019; Chung, Choi, Yoo ve Kim, 2020;Rittichainuwat, Laws, Maunchontham, Rattanaphinanchai, Muttamara, Mouton ve Suksai, 2020; Huete Alcocer ve Lopez Ruzi; 2020) araştırmalarla benzerlik göstermişlerdir. Türkiyede Anadoluda yapılan çeşitli araştırmalarda alternatif turizmin olumlu etkileri (Arpacı, Zengin ve Batman, 2012; Eykay, Dalgı̀n ve Çeken2015; Akyürek vd., 2018; Çakır ve Kodaş, 2020; Zeybek ve Aylar, 2020; Kanca ve Unur, 2020) literatür ile benzerlik göstermiştir.

Turistik destinasyonlarda tanitım ve pazarlama konusuna önem verilmesi sonucu (Alyakut, 2020; Kulınçarslan ve Albayrak, 2020; Rahimi, Hassan ve Tekin, 2020; İnanır, 2019; Šerić ve Marušić, 2019) çalışmaları ile benzerlik göstermektedir. Turistik destinasyonlarda alt ve üst yapı konusuna önem verilmesi gerektiği sonucu (Zengin ve Şeyhanlığlu, 2019; Pestana, Parreira ve Moutinho,2019; Türkay ve Saraç, 2019; Wass, Chandrarathne ve Kumara, 2020) çalışmaları ile benzerlik göstermektedir.

Araştırmacıların Ağr1 destinasyonu ile ilgili zayıf gördükleri veya yapılması gerekenlerle ilgili destinasyonun güçlendirilmesi adına yerel paydaşlara, araştırmacılara çeşitli öneriler geliştirilmiştir;

- Ulaşılabilirlik noktasında uluslararası havalimanına sahip olmasına rağmen Ankara ve İstanbul uçuşlarının saat arası kısadır. Bu nedenle günübirlikçi turisti Ağrı destinasyonu kaçırmaktadır. Bununla ilgili seyahat işletmeleri ile görüşmeler yapılabilir.

- Etkinlikler anlamında gelen turistin fazla vakit geçirmesi için çeşitli etkinlikler yapılmalıdır. Örneğin; İshakpaşa sarayı civarı müsaittir. Orada deve yürüyüşleri vs. güzel bir görüntü verir. Yahut fasıllar, sıra geceleri tarzında akşam etkinlikleri olmalıdır.

- Tanıtım ve pazarlama çalş̧maları arttırlmalıdır. Sosyal medya etkin kullanılmalı ve Ağrı destinasyonu tamamen her özelliği ile tanitılmalıdır.

- Güvenlik konusunda olumsuz bir imaj oluşmaması için yerel paydaşların birlikte çalışı konuyu derinlemesine ele almalar1 gerekmektedir.

- Gastronomi konusunda destinasyonun önemli ürünü olan abdigör köftesi şehrin her yerinde tanıtılmalı ve yiyecek içecek işletmelerinde tanıtımı yapılmalıdır. Çünkü bu noktada Ağrı ilinin neyi meşhur sorusunun cevabı karşılanacaktır.

- Gastronomi konusunda diğer husus yöresel ürünlerin ön planda tutulmasıdır. Yerel peyniri, balı ve tereyağının da tanıtımı yapılmalıdır.

- Hediyelik eşya konusunda il ve ilçe merkezlerinin çarşı1larında Nuh’un gemisi, İshakpaşa sarayı maketleri, anahtarlıklar satışa çıkarılmalıdır. Bu noktada yerel paydaşlar konuyu aydınlatmalıdır ve derinleştirmelidirler.

- Gerek yerel paydaşlar gerekse yerel paydaşların iletişimde olduğu turistler ve bölgede yaşayan araştırmacıların yaptıkları gözlemler sonucu konaklama işletmelerinin zayıf olduğu görülmektedir. Özellikle Diyadin Kaplıcaları bölgesinde tesisleşme çok kötü olduğu dile getirilmiştir. Bu noktada yerel paydaşlara çok işler düşmektedir.

- Tesisleşme ile ilgili bir hususta turistik ürünlerin çevresinde WC, Restoran gibi turistik tesislerin kalite düşüklügü görülmektedir. Bu noktada yerel paydaşlara önemli sorumluluklar düşmektedir.

- Turizm imajı konusunda birçok ölçek bulunmaktadır. Bu konuda Ağrı ilinde turistik ürünleri ile ilgili araştırmalara konu açıktır. Pazarlama noktasında araştırmalar yürütülebilir.

- Alternatif turizm konusunda Türkiye'de veya yurt dışında çalışmalar yürütülebilir. Bu noktada araştırmacılara çok iş düşmektedir.

- Araştırmacılara alternatif turizm ürünleri ile ilgili yerel halkın turizm bilincini ve girişimciliğini artıracak projelerin yapılması̈̈nerilebilir.

- Araştırmacılar özellikle alternatif turizm ve yerel paydaşlar üzerine ölçekler geliştirebilirler.

- Araştırmacılar Ağrı destinasyonunun farklı özellikleri noktasında çalışmalarını yürütebilirler. 
- Destinasyon çok turist çeken bir yer olduğundan turizm akademisyenleri açısından bakir bir çalışma alanıdır.

\section{Etik Beyan}

"Ağr Destinasyonunun Alternatif Turižm Potansiyeline İlişkin Yerel Paydaşlarm Bakeış Açısı" başlıklı çalışmanın yazım sürecinde bilimsel kurallara, etik ve alıntı kurallarına uyulmuş; toplanan veriler üzerinde herhangi bir tahrifat yapılmamış ve bu çalşma herhangi başka bir akademik yayın ortamına değerlendirme için gönderilmemiştir.

\section{Kaynakça}

Ağrn Kültür ve Turizm İl Müdürlüğü. (2020). İnanç Turizmi. Erişim adresi. https://agri.ktb.gov.tr» TR122239/inanc_turizmi.

Ağr1 Valiliği. (2020). Ağr1 Kültür ve Turizm İl Müdürülüğü. Erişim adresi. https://agri.ktb.gov.tr» Ağr1_turizm_il_müdürlügü.

Amerta, I. (2017). The role of tourism stakeholders at jasri tourism village development, karangasem regency. International Journal of Social Sciences and Humanities, 1(2), 20-28.

Akbaba, A., Güvenol, B. ve Sağlam, M. C. (2019). İzmir'deki Türk hamamlarının turizm ürünü olarak değerlendirilmesi.Gastroia: Journal of Gastronomy and Travel Research, 3(4), 640-652.

Akyürek, S., Özdemir, Ö. ve Çeken, H. (2018). Gümüşhane ilinin kırsal turizm potansiyeli ve yerel halkın kırsal turizm hakkındaki görüşleri (Zigana köyü örneği). International Rural Tourism and Development Journal (IRTAD), 2(2), 10-19.

Alrawadieh, Z., Alrawadieh, Z. ve Kozak, M. (2019). Exploring the impact of tourist harassment on destination image, tourist expenditure, and destination loyalty. Tourism Management, 73, 13-20.

Alyakut, Ö. (2020). Destinasyon pazarlaması kapsamında gastronomi bilgi içeriklerinin analizi: Web siteleri üzerine bir inceleme. Türk Turizm Arastrmalar Dergisi, 4(3), 1867-1884.

Arıca, R. (2019). Seyahat acentalarında turistik ürünlerin kişişelleştirilmesinin bir yolu olarak müşterilerle üretim. Türk Turizm Arastrmalar Dergisi, 3(3), 499-516.

Arpacı, Ö., Zengin, B. ve Batman, O. (2012). Karamanın mağara turizmi potansiyeli ve turizm açısından kullanılabilirliği. Karamanoğh Mehmetbey Üniversitesi Sosyal ve Ekonomik. Arastirmalar Dergisi, 2012(2), 59-64.

Arslan, E. S. (2019). Determination of the alternative routes related to nature tourism in burdur.International Journal of Geography and Geography Education (IGGE), 40, 332-346.

Bahar, O. ve Kozak, M. (2012). Turizm ekonomisi. Ankara: Detay Yayıncllk

Başkale, H. (2016). Nitel araştırmalarda geçerlik, güvenirlik ve örneklem büyüklüğünün belirlenmesi,Doku₹ Eylül Üniversitesi Hemsirelik. Fakïltesi Elektronik Dergisi, 9(1), 23-28.

Baytok, A., Pelit, E. ve Soybalı, H. H. (2017). Alternatif Turizm mi turizmde çeşitlilik mi? kavramsal bir değerlendirme. Erzincan Üniversitesi Sosyal Bilimler Enstitiisü Dergisi, Özel sayz-IV, 1-14.

Buhalis, D. ve Michopoulou, E. (2011). Information-enabled tourism destination marketing: Addressing the accessibility market. Current Issues in Tourism, 14(2), 145-168.

Chan, C. S., Nozu, K. ve Cheung, L. (2020). Tourism and natural disaster management process: Perception of tourism stakeholders in the case of kumamoto earthquake in japan. Current Issues in Tourism, 23(15), 1864-1885.

Cham, T. H., Lim, Y. M., Sia, B. C., Cheah, J. H. ve Ting, H. (2020). Medical tourism destination image and its relationship with the intention to revisit: a study of chinese medical tourists in Malaysia. Journal of China Tourism Research, 1-29.

Chin, N., Day, J., Sydnor, S., Prokopy, L. S. ve Cherkauer, K. A. (2019). Exploring tourism businesses' adaptive response to climate change in two great lakes destination communities. Journal of Destination Marketing \& Management, 12, 125-129.

Chung, J. Y., Choi, Y. K., Yoo, B. K. ve Kim, S. H. (2020). Bleisure Tourism Experience Chain: Implications for Destination Marketing. Asia Pacific Journal of Tourism Research, 25(3), 300-310.

Clara, R. A., Simon, D., Noelia, G. ve Barbara, A. (2019). Critical elements in accessible tourism for destination competitiveness and comparison: Principal component analysis from oceania and south america. tourism management, 75, 169-185.

Cömert, M. (2014). Turizm pazarlamasında yöresel mutfakların önemi ve Hatay mutfağı örneği. Journal of Tourism and Gastronomy Studies, 2(1), 64-70.

Çakır, O. ve Kodaş,B. (2020). Resıdents' perceptıons of tourısm potentıal and its effect on supportıng tourism development: The case of Çorum province,GSI Journals Serie A: Advancements in Tourism, Recreation and Sports Sciences (ATRSS), 3(1), 1-16.

Çelik, S. (2018). Alternatif turizm.Uluslararası Sosyal Arastrmalar Dergisi, 11(56), 193-204.

Çetin, Y. (2009). Taribi kalhntlar ve kültürel değerleri ile Ağgr. İstanbul: T.C. Ağrn Valiliği.

Düşmezkalender, E. ve Metin, M. (2019). Alternatif turizme yönelik bibliyometrik bir araştırma. Selçuk Üniversitesi Sosyal Bilimler Meslek Yüksekokulu Dergisi, 22(2), 813-824. 
Eid, R., El-Kassrawy, Y. A. ve Agag, G. (2019). Integrating destination attributes, political (in) stability, destination 1mage, tourist satisfaction, and intention to recommend: A study of UAE. Journal of Hospitality \& Tourism Research, 43(6), 839-866.

Ekiz, D. (2009). Bilimsel araştırma yöntemleri (2. Baskı). Ankara: Anı Yayıncılık.

Eykay, İ., Dalgın, T. ve Çeken, H. (2015). İnanç turizmi potansiyeli açısından Antakya'nın değerlendirilmesi. Journal of Life Economics, 2(2), 59-74.

Geçit, M. S. (2013). Hoca Ahmed Yesevî ile Şeyh Ahmed-i Hânînin Divân-1 Hikmet ve Mem u Zin eserlerindeki itikadî esasların mukayesesi. Dinbilimleri Akademik. Araştırma Dergisi, 13(1), 123-156.

Getz, D. (1997). Event management \& event tourism, Cognizant Communication Corporation, New York.

Gössling, S., Scott, D. ve Hall, C. M. (2020). Pandemics, tourism and global change: A rapid assessment of COVID19. Journal of Sustainable Tourism, 1-20.

Hacıoğlu, N. ve Avcıkurt, C. (2008). Turistik ürün çeșitlendirmesi, Ankara: Nobel Yayınevi.

Huete Alcocer, N. ve López Ruiz, V. R. (2020). The role of destination image in tourist satisfaction: The case of a heritage site. Economic research-Ekonomska istraživanja, 33(1), 2444-2461.

Isaac, R. K. ve Eid, T. A. (2019). Tourists' destination image: An exploratory study of alternative tourism in palestine. Current Issues in Tourism, 22(12), 1499-1522.

İnanır, A. (2019). Turistik destinasyon yönetiminde paydaşlar arası ilişkiler: Göller yöresi örneği. Türk Turiæm Arastirmalar Dergisi, 3(3), 517-541.

Jovicic, D. (2016). Cultural tourism in the context of relations between mass and alternative tourism. Current Issues in Tourism, 19(6), 605-612.

Kanca, B. ve Unur, K. (2020). İstanbul'un düğün turizmi potansiyelinin değerlendirilmesi. Seyahat ve Otel Issletmeciliği Dergisi, 17(2), 311-327.

Karabulut, K. ve Köksal, Y. (2018). Ağr ilinin turizm potansiyeli ve turizmi geliştirmeye yönelik çözüm önerileri (Edt. Karabulut, K.).Ağrı İlinin Sosyo-Ekonomik Profili, Ankara: AİÇÜ Yayınları.

Karabulut, K. veKöksal, Y. (2019). İnanç turizmi ve bölgesel kalkınmaya etkisi Ağrı ili örneği. Ağr İbrabim Çegen Üniversitesi Sosyal Bilimler Enstitüsü Dergisi, 5(1), 83-104.

Kaya, F. (2016). Ağrı Dağı'nın Turizm Potansiyeli ve Değerlendirme Durumu, Marmara Coğrafya Dergisi/ Marmara GeographicalReview, Say1: 34, 217-229.

Kılıçarslan, D. ve Albayrak, T. (2020). Destinasyon pazarlama organizasyonlarının sosyal medya performansının kiyaslanmas1. Anatolia: Turizm Araștırmalar Dergisi, 31(2), 149-160.

Kozak, M.A. ve Bahçe, A.S. (2012). Öz̧el ilgi turizmi (2.Bask1). Ankara: Detay Yayıncılık.

Kuq, B. ve E., Hasanaj, P. (2020). Development of alternative tourism in Kosovo-Peja region. Baltic Journal of Real Estate Economics and Construction Management, 8(1), 93-101.

Lee, C. S., Martin, D., Hsieh, P. F. ve Yu, W. C. (2020). Principles of value creation in event tourism: Enhancing the competitiveness of regional clusters. Journal of Global Scholars of Marketing Science, 30(4), 437-453.

Nakip, M. (2013). Pazarlamada araștırma teknikleri.Ankara: Seçkin Yayıncılık.

Nunkoo, R. ve Gursoy, D. (2017). Political trust and residents' support for alternative and mass tourism: An improved structural model. Tourism Geographies, 19(3), 318-339.

Ön Esen, F. ve Bahar, O. (2019). Thermal tourism in Afyonkarahisar in terms of the relationship between destination 1mage, tourist satisfaction and destination loyalty, Journal of Turkish Tourism Research, 3(4), 949-963.

Pestana, M. H., Parreira, A. ve Moutinho, L. (2020). Motivations, emotions and satisfaction: The keys to a tourism destination choice. Journal of Destination Marketing \& Management, 16, 1-9.

Prince, S. ve Ioannides, D. (2017). Contextualizing the complexities of managing alternative tourism at the community-level: a case study of a nordic eco-village. Tourism Management, 60, 348-356.

Rahimi, R., Hassan, A. ve Tekin, O. (2020). Augmented reality apps for tourism destination promotion. Destination Management and Marketing: Breakthroughs in Research and Practice, 1066-1077.

Rena İnsaat. (2020).Projelerimiz. Erişim adresi. http://www.renainsaat.com/projelerimiz > ishakpasa-sarayi.

Rittichainuwat, B., Laws, E., Maunchontham, R., Rattanaphinanchai, S., Muttamara, S., Mouton, K. ve Suksai, C. (2020). Resilience to crises of Thai MICE stakeholders: A longitudinal study of the destination image of Thailand as a MICE Destination. Tourism Management Perspectives, 35, 1-15.

Samarathunga, W. ve Gamage, D. (2020). Alternative tourism as an alternate to mass tourism during the PostCOVID-19 recovery phase: The case of Sri Lanka. Sage Submissions. Sri Lanka: Preprint.

Šerić, N. ve Marušić, F. (2019). Tourism promotion of destination for swedish emissive market. Advances in Economics and Business, 7(1), 1-8.

Şahin, G. G. ve Ünver, G. (2015). Destinasyon pazarlama aracı olarak gastronomi turizmi: İstanbul'un gastronomi turizmi potansiyeli üzerine bir araştırma. Journal of Tourism and Gastronomy Studies, 3(2), 63-73.

Ulusan, Y. ve Batman, O. (2010). Alternatif turizm çeşitlerinin Konya turizmine etkisi üzerine bir araştırma. Selçuk Üniversitesi Sosyal Bilimler Enstitüsü Dergisi, 23, 243-260.

Taşkın, E., Şener, H. Y. ve Bilgiç, B. (2020). Eskişehir destinasyon markasının geliştirilmesinde lületaşı. Işletme Bilimi Dergisi, 3-4.

Timur, M. N., Çevik, S. ve Kıcır, G. K. (2014). Etkinlik turizmi: Kültür başkenti etkinliklerinin başarı unsurları üzerine bir değerlendirme. Akademik Sosyal Araștırmalar Dergisi, 2(1), 56-83 
Türkay, O. ve Saraç, Ö. (2019). Altyapı, üstyapı ve çevre sorunlarının turist şikâyetleri kapsamında değerlendirilmesi ve yerel yönetimlerin çözüm potansiyeli: Antalya örneği. Gümüshane University Electronic Journal of the Institute of Social Science/ Gümüshane Üniversitesi Sosyal Bilimler Enstitüsü Elektronik. Dergisi, 10(Ek Say1), 98-110.

Wass, M. S. R., Chandrarathne, S. G. U. S. ve Kumara, U. A. (2020). Impact of management and development of destination attributes on coastal tourists' visitor experience, Negombo, Sri Lanka. Middle East, 7(47), 4-7.

Wearing, S. ve Neil, J. (2009). Ecotourism: Impacts, potentials and possibilities (2 ${ }^{\text {nd }}$ Edition). Oxford: Elsevier, ButterworthHeinemann.

Wong, J. W. C., Lai, I. K. W. ve Tao, Z. (2020). Sharing memorable tourism experiences on mobile social media and how it influences further travel decisions. Current Issues in Tourism, 23(14), 1773-1787.

Yazgan, Ş. ve Kadanalı, E. (2012). Ağrn ilinin kırsal turizm potansiyelinin değerlendirilmesi. Karamanoğlu Mehmetbey Üniversitesi Sosyal ve Ekonomik. Arastirmalar Dergisi, 2012(1), 5-10.

Yıldırım, A. ve Şimşek, H. (2008). Sosyal bilimlerde nitel araştırma yöntemleri (6. Baskı). Ankara: Seçkin Yayıncılık.

Yıldırım, G. (2020). Halkla ilişkilerde paydaş teorisi perspektifinden kurum içi iletişimin çalışanların kurumsal bağlilıklarına etkisi. Selcuk İletisim Dergisi, 13(2), 438-470.

Zaman, M., Polat, S. ve Özdemir, M. (2000). Diyadin kaplicaları. Doğu Coğrafya Dergisi, 4, 349-390.

Zengin, B., Koç, D. E. ve Ulama, Ş. (2019). Kastamonu ilinin doğa turizmi potansiyelinin alternatif turizm kapsamında değerlendirilmesi. Safran Kültür ve Turiz̨m Arastırmalar Dergisi, 2(2), 251-274.

Zengin, B. ve Şeyhanlığlu, H. Ö. (2019). Destinasyon pazarlamasının yerel kalkınmaya etkileri: Şanlıurfa örneği. Journal of Tourism and Gastronomy Studies, 7(4), 2977-2992.

Zeybek, H. İ., Aylar, F. ve Dinçer, H. (2020). Değirmendere şelalesi (Ulus/Bartın), doğal ortam özellikleri ve turizm potansiyeli. Journal of Graduate School of Social Sciences, 24(1), 333-357.

Ziyadin, S., Koryagina, E., Grigoryan, T., Tovma, N. ve Ismail, G. Z. (2019). Specificity of using information technologies in the digital transformation of event tourism. International Journal of Civil Engineering and Technology, 10(1), 998-1010.

\section{EXTENDED ABSTRACT}

While escaping from mass tourism within the framework of the search for alternative, it directs individuals to alternative tourism types, it has also gained importance for the development and recognition of destinations. Thus, the foreign currency and money left by the tourists coming to the region will minimize the economic difference between the regions on a national basis. The aim of the study is to examine the opinions of local stakeholders living in the destination A $\breve{g r} 1$ and the tourism potential of the destination on alternative tourism, and it was designed as a qualitative research. For this purpose, the alternative tourism potential of pain and its contributions to stakeholders were investigated. The research is important because it is conducted specifically for pain and reveals the local stakeholders' perspective on alternative tourism. The fact that studies on alternative tourism have not yet been carried out in the province of Ağrn will make the study an original study that sheds light on the future.

The research data were obtained from some local government representatives, non-governmental organizations, local people, public employees, self-employed professionals and some private sector enterprises (entrepreneurs) in Ağr1, using qualitative data collection techniques, using face-to-face interview technique. Research data were collected between 01 September 2020 - 01 October 2020 in Ağr1. The data were collected through interviews from experts who have command of the subject and the region. Appointments were made from the sample included in the study and some information was given about the subject and purpose of the study. During the interview, the data were prepared as text in a Word file with the voice recordings and notes. All interviews were conducted with the permission of the participants. Within the scope of the research, 16 people were interviewed. The average duration of the interviews is between 30 and 40 minutes.

The study is based on examining the Ağr1 destination in terms of economy, infrastructure, entrepreneurship level, social life, tourism enterprises, local handicrafts, promotion and marketing. According to the research findings, especially; Giving importance to promotion, image studies, quality tourism enterprises, accessibility, media usage, increasing the activities and attractiveness were discussed. It was observed that the local people had information about alternative tourism and even gave comprehensive information about the city's initiatives for alternative tourism. It is of the opinion that the necessary importance is given to alternative tourism products. It was stated that the pain province, which has potential for tourism, was not given enough attention before, but there are hopes for the future and projects are being prepared.

The local people state that tourism has economic contributions, and even that they cannot attract enough tourists, if tourists are encouraged, every segment of the people will benefit at this point. The 
thought that tourists leave money in every city they visit is dominant. Local people think that alternative tourism will stimulate social life and even increase cultural and artistic activities in the city. The idea that tourist means the mobilization of social life is at the forefront. It has been concluded that there are infrastructural problems in general and the development took place for a few years. It was stated that the biggest problem in the city was at the point of power outage and that the city center was in a better condition.

They find the condition of the facilities weak. In general, they stated that a renovation method should be used and even a quality service should be provided for star increase. In addition, local stakeholders complain about the lack of high-star hotels. In general, they found the level of entrepreneurship weak and expressed their views on the point that it will develop over time. In particular, they expressed their discomfort that the wealthy and wealthy families of the city invest in metropolitan cities or neighboring provinces instead of investing in the city. Participants stated that they would be honored by the hospitality they want tourists to come and even they want them to come continuously.

Participants stated that, thanks to alternative tourism, handicraft products, carpets, art objects, especially marbling, gilding and traditional Turkish art products are sold, and even the centers that sell products earn money. In the light of the findings, some suggestions were tried to be developed for local stakeholders and researchers. These recommendations; although it has an international airport at the point of accessibility, the hours between Ankara and Istanbul flights are short. For this reason, the excursion tourist misses the destination in Ağrı. Discussions can be made with travel companies about this.

Various activities should be organized so that the tourists who come in terms of activities spend more time. For example; Ishakpaşa Palace is available around. There camel walks etc. It gives a beautiful image. Or chapters should be evening events in the style of queue nights. Promotion and marketing activities should be increased. Social media should be used effectively and the destination of Ağr1 should be introduced with all its features. In order to avoid a negative image about security, local stakeholders should work together and discuss the issue in depth. Abdigör meatball, which is an important product of the destination in gastronomy, should be promoted all over the city and promoted in food and beverage businesses. Because at this point, the answer to the famous question of what is the pain province will be met. Another issue in gastronomy is to prioritize local products. Local cheese, honey and butter should also be promoted.

Noah's ship, İshakpaşa palace models and keychains should be put on sale in the bazaars of the provincial and district centers. At this point, local stakeholders should enlighten and deepen the issue. As a result of the observations made by tourists and researchers living in the region with whom both local stakeholders are in contact with local stakeholders, it is seen that accommodation businesses are weak. Especially in the Diyadin Hot Springs area, it has been stated that the establishment is very bad. At this point, a lot of work falls on local stakeholders. Regarding the establishment, low quality of touristic facilities such as WC and Restaurant is observed around the touristic products. At this point, important responsibilities fall on local stakeholders. There are many scales regarding the tourism image. In this regard, researches on touristic products in the province of Ağr1 are open to research. Research can be conducted at the marketing point. Alternative tourism in Turkey or abroad outside of work can be carried out. At this point, researchers have a lot of work to do. It may be suggested to researchers to make projects that will increase the tourism awareness and entrepreneurship of the local people regarding alternative tourism products. Researchers can develop scales especially on alternative tourism and local stakeholders. 